\title{
The Energy Challenge in Hungary: A Need for More Complex Approaches
}

\author{
Edina Vadovics
}

Abstract Vadovics first describes the motivations behind and objectives for energy policy in Hungary. This is followed by an overview of sustainable household energy consumption initiatives, and their classification according to the ENERGISE problem framing typology. It is shown that although the initiatives are very diverse, they are dominated by those focusing on individual behaviour and technology change. Then, one of the initiatives, a local climate club, is introduced and analyzed. It is described how complex initiatives, including small group-based ones, can support change towards, and create capacities for, more sustainable energy use. The chapter then concludes with policy conclusions relevant to both Hungary and Europe.

Keywords Energy policy - Sustainable energy consumption • Problem framing $\cdot$ Behaviour change $\cdot$ Small groups

\author{
E. Vadovics $(\bowtie)$ \\ GreenDependent Institute, Gödöllő, Hungary \\ e-mail: edina@greendependent.org \\ (C) The Author(s) 2019 \\ F. Fahy et al. (eds.), Energy Demand Challenges in Europe, \\ https://doi.org/10.1007/978-3-030-20339-9_8
}




\section{INTRODUCTION}

Hungary is poor in fossil fuel resources but at the same time close to $90 \%$ of its total primary energy supply comes from fossil fuel and nuclear sources (MEKH 2017). Thus, dependence on external fossil fuel and non-renewable resources is one of the most important issues facing energy and climate policy-makers. With regards to energy system ownership structures, there is an explicit government policy to establish a stateowned, centralised infrastructure as the main means for the provision of energy for the household sector, one of the largest final energy user sectors with $31 \%$, followed by the transportation $(22 \%)$ and industrial (21\%) sectors (MEKH 2017). Perhaps it is not surprising that Hungary is lagging behind other European countries in terms of both renewable energy utilisation and community energy, as well as supporting the transition to a prosumer culture, all of which would require a more flexible and less centralised energy system. At the same time, per capita carbon emissions in Hungary are lower than the European average, and, in fact, lower than in most European countries (EEA 2019, based on data from 2016). This fact if considered together with the rather high (cc. 40\%) saving potential in the household sector means that there is a so far unrealised potential towards a low-carbon economy (Energiaklub 2011). Although, according to the latest Eurobarometer survey (2018), climate change is not considered to be a central issue by Hungarian citizens, it is worth noting that there is a higher than average (76\%) support for the common European energy policy (Bart et al. 2018).

\section{Socio-Material Dynamics of Household Energy UsE IN Hungary}

With the household sector taking up the largest share of final energy use (31\%), building energy efficiency is an important factor in energy and climate policy. This is especially so given the fact that Hungary's building stock is technically obsolete, with a large proportion of buildings lacking adequate insulation and/or energy-efficient heating systems (Bart et al. 2018 ). About $86 \%$ of homes are owned privately, and the share of the population living in detached houses is relatively high, 63\% (Eurostat 2018). These households often use a mix of fuels for heating, typically natural gas and wood. About $30 \%$ of the population live in flats, a considerable proportion of which are blocks of flats built using industrial 
technologies (Eurostat 2018; Jensen et al. 2018). The use of district heating and other joint/community solutions are hindered by negative social attitudes towards public or joint ownership schemes (Jensen et al. 2018).

A considerable share of society (around 35\%) live under the 'subsistence' levels and $21 \%$ live in fuel poverty (Fülöp and Lehoczki-Krsjak 2014). 27\% of homes have inadequate walls and roofs, and $9 \%$ of the population are unable to keep their homes warm (Eurostat in HBS-FoE Hungary 2018). Within the European Union, Hungary has one of the highest rates of housing deprivation (Eurostat 2018). Thus, the affordability of energy is a major issue and the popular policy of the government is to regulate the price of energy.

As for the use of energy, the level of consciousness is low. The majority of the households do not follow their energy consumption data and the household appliances stock is inefficient on a large scale (Slezák et al. 2015). On the other hand, in a survey the Hungarian population expressed willingness and interest in energy-efficient home improvements (Fülöp and Kun 2014), but, on the whole, households lack the financial resources to act on this interest.

\section{Energy Policy in Hungary}

The most important goals of Hungarian energy policy (MND 2012) are the provision of affordable energy, long-term sustainability, supply security and economic competitiveness. Special emphasis is placed on tackling the energy dependency of the country by means of: (i) energy savings; (ii) increasing the share of renewable energy sources; (iii) safe nuclear energy and the electrification of transport based on this; (iv) creating a bipolar agriculture (food production and energy-geared biomass production); and (v) better integration to the European energy infrastructures (Jensen et al. 2018).

A characteristic feature of recent energy policy is the pivotal role of the government. In this context, important measures were taken by the government such as setting up a 100\% state-owned National Public Utility Company (next to the private utility companies operating in the country) to ensure the security of energy supply. It is an explicit policy of the government to keep energy prices low. Related measures have included the appointment of a governmental commissioner and the regulation of utility prices for the household sector (Jensen et al. 2018). 
In the context of energy saving and efficiency, the main focus is put on the household sector and the building stock. However, during the last few years, relevant policy support has been volatile (e.g., relevant policies had been announced and then re-called), sporadic, short-term with resources running out in days, and actual incentives have targeted the public rather than the household sector (Bart et al. 2018; HBS-FoE Hungary 2018; Jensen et al. 2018).

There are several gaps and controversies in recent Hungarian energy and climate policy that give rise to discussions among experts in the sector. It is claimed that the potential for energy saving is higher than that predicted by the government. Thus, national plans are not ambitious enough (Slezák et al. 2015; Bart et al. 2018). Additionally, the expected growth rate of energy consumption is disputed, and alternative estimations argue that the planned capacity enlargement of the Paks Nuclear Power Plant is not necessary in view of the country's potential for energy efficiency improvements (Lechtenböhmer et al. 2016). There is also a debate about the regulation of household energy prices, especially as it took place without any differentiation based on income levels, housing deprivation status, etc. (Jensen et al. 2018).

Finally, it needs to be noted that in line with EU requirements, the process of developing the Integrated National Energy and Climate Plan has begun in Hungary. It is expected that the Plan, once adopted, may bring some changes in the policy context.

\section{Trends in Household Energy Campaigns in Hungary}

Governmental energy-related campaigns have been dominated in the last years by the 'war on utility costs' - an overall populist price policy of the government (Slezák et al. 2015). To a lesser degree, in line with the Energy- and Climate Awareness-Raising Action Plan of Hungary, policies have been supported by certain awareness-raising activities.

Regarding monetary incentives, the main financial instrument managed by the central government to promote investments aimed at furthering energy efficiency in households has been the so-called 'Warmth of the Home Programme' grant scheme. Set up in 2014, it has provided financial support in several phases. For instance, grants are available for the replacement of inefficient household appliances, inefficient doors and windows, etc. However, the available funding has been insufficient and has always been sourced out within days, indicating a high level of interest from the population (HBS-FoE Hungary 2018; Jensen et al. 2018). 
In addition, interest-free soft loans for energy efficiency improvements are available both for the household and the SME sectors (Jensen et al. 2018). Some municipal governments also provide incentives for energy efficiency renovations for households, especially for those living in apartment blocks (Slezák et al. 2015).

\section{Sustainable Energy Consumption Initiatives (SECIs) IN HuNGARY}

A recent review conducted in the framework of the European ENERGISE project revealed that in line with findings for all European countries (see Chapter 2), Hungarian SECIs are dominated by those focusing on individual behaviour and technology change (see Table 8.1). Nonetheless, the Hungarian SECIs reviewed in the ENERGISE project are very diverse in terms of their objectives, target groups, the type of organisations implementing them, the methods they apply, their funders, etc. Some SECIs are directly impacted by the energy policies of Hungary and the European Union, as support and funding available for them is determined by policy objectives. Other SECIs are specifically created to aid the implementation of policies, or prepare various stakeholders for the implementation of a particular policy. For example, projects have been carried out to educate stakeholders about new energy regulations and building directives. There are, also, less technology-oriented projects

Table 8.1 Number of national SECIs according to their problem framing in Hungary

Changes in Everyday Life Situations 
in this category, for example, those that are intended to bring about attitude and behaviour change to prepare the general population for the impacts of climate change and to motivate more sustainable energy use patterns.

On the other hand, SECIs often respond to needs that are not met by policy, and aim to go beyond what is requested by policies, or even challenge policies. Consequently, these kinds of SECIs are often funded from sources other than the national government: from private foundations, companies or local municipalities, from European frameworks, and, still less often, from community funding (e.g., crowdfunding). Examples of these types of SECIs include the Biomass briquettes programme created to provide an alternative, environmentally friendly fuel source as well as employment opportunities for a community living in energy poverty, or the very innovative Climate ticket (Klimajegy) initiative that made it possible for individuals and organisations in a specific region to voluntary compensate their carbon footprint through supporting local sustainable energy projects (e.g., installing solar panels, planting trees).

Both of these categories include initiatives that correspond to each of the four problem framings presented in Table 8.1. Below, we introduce an initiative that was categorised as one that brings about 'changes in complex interactions'.

\section{Case Study: Gödöllő Climate Club}

The Climate Club was established in 2009 by GreenDependent Association in order to raise awareness of climate change issues in households, establish links between climate change and household consumption, and create a sense of responsibility for consumption and lifestyle-related emissions in households. Climate $\mathrm{Club}^{1}$ members live in or around Gödöllő, a town in Central Hungary. The Club was formed as part of a European research project called Changing Behaviour. ${ }^{2}$ Thus, it started as a pilot project, but is ongoing to this day (February 2019).

\footnotetext{
${ }^{1}$ More information about the Gödöllő Climate Club can be found at http://klimaklub. greendependent.org/en.html.

${ }^{2}$ To learn more about the Changing Behaviour project, please visit http://www.energychange.info/.
} 
The core activity of the Club is its monthly meetings where members discuss, in an informal setting, climate change, energy-related and environmental issues, ideas and concerns. Alternatively, Club members invite experts to have a discussion or give a presentation on a given topic of interest.

\section{Methods for Intervention}

The Changing Behaviour research project studied successful and less successful demand-side management programmes in an effort to establish general success factors (Mourik et al. 2009; Vadovics and BozaKiss 2013). As a partner in the project, GreenDependent attempted to incorporate many of the identified success factors in the intervention methodology in order to create lasting change. For example, creating a community is important so that participants do not feel alone in their efforts; besides, they can share experience and learn from each other, too. Some methods and tools were developed to allow for flexibility as well as to cater to the communication and learning needs of people with different backgrounds and various levels of experience.

Building on the findings of the Changing Behaviour project (Heiskanen et al. 2010), Table 8.2 summarises how small groups, and, in particular, the Climate Club, can help overcome barriers to behaviour change and, at the same time, create capacities and skills for change.

Households were not involved in the design phase of the pilot project, as it was based on 'best practice methodology' identified in the Changing Behaviour project. Apart from this, however, they are invited to take an active role in planning the content of the monthly meetings, in initiating activities in the larger community, and in the organisation of the club meetings, e.g., by providing homemade food and drinks.

\section{Framing the Energy Challenge}

The energy and climate change challenge has been communicated to and discussed with households as a challenge that potentially has an impact on all aspects of their lives, which, in turn, has an impact on how serious the challenge is going to be. Households were invited to consider their everyday life from the point of view of how much energy they use and what they use it for, taking a systemic perspective. They also considered how they can limit the impact of energy and climate change in 


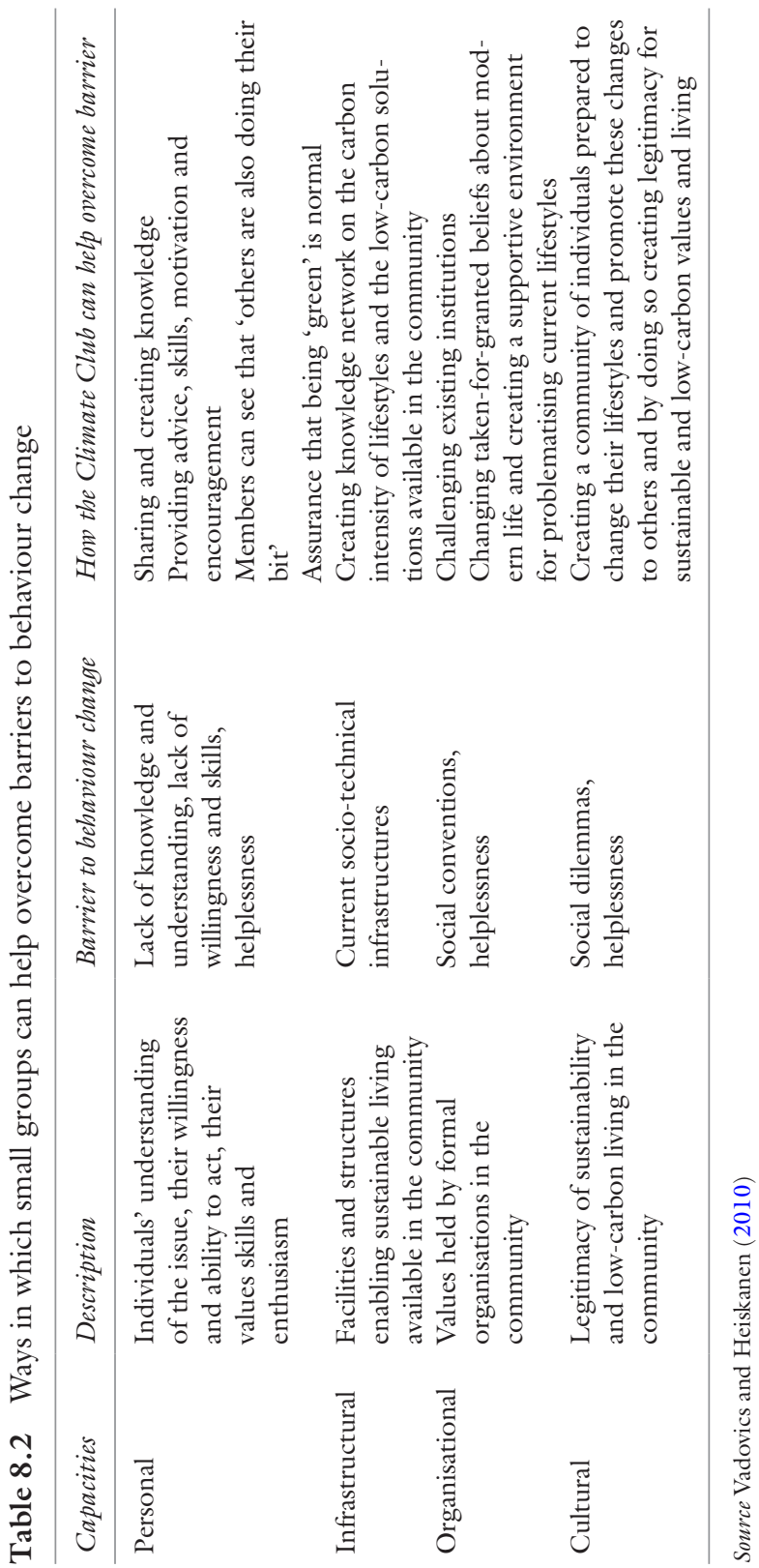


their individual homes and everyday routines by changing their practices and behaviour, and by making technological changes, e.g., through energyefficient home improvements. Since they were part of the group, they were encouraged to discover and consider the social aspects of energy use, e.g., the conventions and expectations that govern their everyday practices, the things they can influence and can perhaps change together, and the local opportunities, knowledge and skills available for making more sustainable energy use possible. After spending some time together as members of the same Club, they became motivated to get engaged in the local community, and organise awareness-raising activities at community events. The Climate Club also engages in areas more indirectly related to energy consumption, such as producing food, dealing with waste, and so on. The Club works with other NGOs in the town and has been networking with similar initiatives in Hungary.

\section{Outcomes, Successes of the Initiative}

Because of its more informal nature, there was no comprehensive study done on the carbon footprint reduction or energy saving achieved by the Gödölló Climate Club members, but there are indications that most members achieved at least $10 \%$ reduction in energy use since they joined the Club. More importantly, the Climate Club has become a small group of dedicated individuals who appreciate the additional knowledge and the sense of community as a primary value provided by the monthly meetings. It is clear that most members feel closely associated with the group, and have a feeling of ownership, which seems to be increasing with time (Vadovics and Boza-Kiss 2013). Overall, the initiative is considered to be a success story, with members continuing to meet to discuss environmental and energy issues, as well as to take action.

\section{Conclusion}

The example of the Gödöllö Climate Club is an interesting SECI for various reasons. Firstly, it was conceived as a pilot project in a European research project. The methodology that was piloted and evaluated in the project was used later for the development of larger (national and international) projects. Secondly, since the Climate Club is still active after nine-ten years, it is a good example of how a pilot project can turn into a continuous project, partly run by the community, and partly by 
the organisation that piloted it originally. Thus, an important lesson learnt is that well-planned projects with impact can continue successfully beyond the pilot and fully funded stage even though this continuation was entirely dependent on the organisation managing it and the local community, as there was no support provided at either the national or European level.

Finally, although the Gödöllo" Climate Club is an example of how a SECI can be designed to create change in complex relations, the majority (more than $75 \%$ ) of the SECIs reviewed for Hungary focus on individual behavioural change and technological aspects of sustainable energy consumption (see Table 8.1). These are important factors, and need to be tackled in initiatives, but there is need to integrate them with social considerations, such as how energy is used, what it is used for, and the communities within which it is used. Since policies have a great influence on what kind of SECIs are implemented and how change is understood to happen, there is also need at that level to take the social aspects of energy consumption into consideration.

Acknowledgements I would like to express my gratitude to colleagues who have contributed in various ways to previous versions of this paper. To József Slezák, who has provided input that greatly assisted me in drafting the sections related to energy policy in this paper, and to Gergő Horváth, Andrea Király, Szandra Szomor and Kristóf Vadovics who provided additional support with background research and data collection.

\section{REFERENCES}

Bart, I., Csernus, D., \& Sáfián, F. (2018). Analysis of climate-energy policies \& implementation in Hungary. National Society of Conservationists-Friends of the Earth Hungary.

Energiaklub. (2011). Negajoule 2020-Energy efficiency potential of Hungarian residential buildings. Budapest, Hungary.

EEA (European Environment Agency). (2019). EEA greenhouse gas-Data viewer. Available at https://www.eea.europa.eu/data-and-maps/data/dataviewers/greenhouse-gases-viewer. Last accessed 11 February 2019.

Eurostat. (2018). Housing statistics. Based on data extracted May 2018. Available at https://ec.europa.eu/eurostat/statistics-explained/index.php/ Housing_statistics\#Tenure_status. Last accessed 28 February 2019. 
Fülöp, O., \& Kun, Zs. (2014). Lakossági Energiahatékonysági Barométer 2014. ENERGIAKLUB Szakpolitikai Intézet és Módszertani Központ, Budapest, Hungary.

Fülöp, O., \& Lehoczki-Krsjak, A. (2014). Energiaszegénység Magyarországon. Statisztikai Szemle, 92, 8-9.

Heinrich Böll Stiftung and National Society of Conservationists-Friends of the Earth Hungary (HBS-FoE Hungary). (2018). Energia Atlasz 2018. Tények a megújuló energiaforrásokról Európában.

Heiskanen, E., Johnson, M., Robinson, S., Vadovics, E., \& Saastamoinen, M. (2010). Low-carbon communities as a context for individual behavioural change. Energy Policy, 38(12), 7586-7595.

Jensen, C., et al. (2018). 30 national summary briefs of national energy supply and demand. ENERGISE-European Network for Research, Good Practice and Innovation for Sustainable Energy, Grant Agreement No. 727642, Deliverable 2.5. Specific chapter on Hungary available at http://www. energise-project.eu/sites/default/files/content/D2.5_Hungary.pdf. Last accessed 28 February 2019.

Lechtenböhmer, S., Prantner, M., Schneider, C., Fülöp, O., \& Sáfián, F. (2016). Alternative and sustainable energy scenarios for Hungary. Budapest, Hungary: Zöld Múhely Alapítvány.

MEKH (Hungarian Energy and Public Utility Regulatory Authority). (2017). Hungarian Energy Balance 2017.

MND. (2012). Nemzeti Fejlesztési Minisztérium/Ministry of National Development (MND). National Energy Strategy 2030.

Mourik, R. M., et al. (2009) Past 10 year of best and bad practices in demand management: A meta analysis of 27 case studies focusing on conditions explaining success and failure of demand-side management programmes. Deliverable 4 of the Changing Behaviour project.

Slezák, J., Vadovics, E., Trotta, G., \& Lorek, S. (2015). Consumers and energy efficiency-Country report for Hungary. An inventory of policies, business and civil initiatives at the national level, focusing on heating, hot water and the use of electricity. December 2015. EUFORIE-European Futures for Energy Efficiency.

Vadovics, E., \& Boza-Kiss, B. (2013, June). Voluntary consumption reductionExperience from three consecutive residential programmes in Hungary. Residential energy master as a new carrier? In Proceedings of the SCORAI Workshop, Istanbul.

Vadovics, E., \& Heiskanen, E. (2010, October 26-29). Understanding and enhancing the contribution of low-carbon communities to more sustainable lifestyles: The case of the Gödöllo" Climate Club in Hungary. Poster presented at the ERSCP-EMSU conference in Delft, Holland. 
94 E. VADOVICS

Open Access This chapter is licensed under the terms of the Creative Commons Attribution 4.0 International License (http://creativecommons.org/licenses/ by $/ 4.0 /$ ), which permits use, sharing, adaptation, distribution and reproduction in any medium or format, as long as you give appropriate credit to the original author(s) and the source, provide a link to the Creative Commons license and indicate if changes were made.

The images or other third party material in this chapter are included in the chapter's Creative Commons license, unless indicated otherwise in a credit line to the material. If material is not included in the chapter's Creative Commons license and your intended use is not permitted by statutory regulation or exceeds the permitted use, you will need to obtain permission directly from the copyright holder.

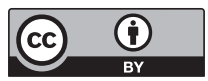

